\begin{tabular}{|l|l|l|l|l|}
\hline Internat. Rev. Hydrobiol. & $\mathbf{8 6}$ & 2001 & 3 & $317-335$ \\
\hline
\end{tabular}

INGO SCHEWE

Alfred-Wegener-Institute for Polar and Marine Research, Columbusstraße, 27568 Bremerhaven, Germany, e-mail: ischewe@awi-bremerhaven.de

\title{
Small-Sized Benthic Organisms of the Alpha Ridge, Central Arctic Ocean
}

key word: Arctic Ocean, ice coverage, deep-sea, meiobenthos, foraminifera, nanofauna, microbial biomass

\begin{abstract}
Abundance, biomass and activity of the small-sized benthic organisms (bacteria to meiofauna, including foraminifera) was studied in summer 1998 during the expedition ARK XIV/1a to the Amerasian area of the perennially ice covered central Arctic Ocean. With the help of two icebreakers, the German research vessel POLARSTERN and the Russian nuclear-powered ARCTICA, it was possible to reach this remote, heavily ice-covered region in order to carry out the first benthic investigations. These focus on effects on the benthic community of the expected low food availability under perennial ice coverage. Bacterial and meiofaunal abundances were determined by direct counting. Biomass determinations on bacteria and nematodes were undertaken by size-imaging techniques. In addition biochemical analyses were carried out to estimate food availability (as sediment-bound chloroplastic pigments indicating phytodetritus) at the sea floor, the total microbial biomass (TMB; i.e. the total amount of sediment inhabiting bacteria, flagellata, protozoa and small metazoa, estimated by phospholipid quantification) and the potential bacterial activity (turnover rates of ester-cleaving exoenzymes). Concentrations of chloroplastic pigment equivalents (CPE) in the main target area (Alpa-Ridge) ranged between $0.10 \pm 0.02$ and $0.17 \pm 0.04 \mu \mathrm{g} / \mathrm{ml}$. A 2-3 times higher concentration was determined at a station on the Lomonosov Ridge crest $(0.40 \pm 0.15 \mu \mathrm{g} / \mathrm{ml})$. The standing stock of meiobenthic organisms (including foraminiferans) was extremely low and varied between $72 \pm 17$ individuals $10 \mathrm{~cm}^{-2}$ in the deep Makarov Basin $(3,170 \mathrm{~m})$ and $190 \pm 56$ individuals $10 \mathrm{~cm}^{-2}$ on the Alpha Ridge $(1,470 \mathrm{~m})$. Significantly higher numbers (U-test, $p=0.049)$ were found on the Lomonosov Ridge $(297 \pm 82$ individuals $10 \mathrm{~cm}^{-2}$ ). Meiobenthic abundances from the area of investigations, were up to ten times lower than those reported from non-ice covered deep-sea regions. However a significant water depth depending decrease of meiobenthic abundances was still detectable.

A comparison of biomass data determined by volumetric measurements and biochemical methods showed that about $67 \%$ of the TMB are held by organisms of nanofauna size $(2-32 \mu \mathrm{m})$, approx. $32 \%$ belongs to bacteria. Only $0.5-1.5 \%$ of the TMB were held by metazoan meiofauna.
\end{abstract}

\section{Introduction}

The expedition ARK-XIV/1a of the German RV "Polarstern" in summer 1998 offered the unique opportunity to penetrate insufficiently explored areas of the central Arctic Ocean. The expedition has allowed quantitative studies on the deep-sea benthos of the Alpha Ridge region, a submarine mountain chain discovered almost 40 years ago by American ice drift stations (Hunkins, 1961). The main goal of the expedition was to reach the Alpha Ridge and to perform a predominantly geological program. Therefore only a limited number of biological samples were taken. However, the present study provides the first quantitative data on the small-sized sediment-inhabiting organisms (including bacteria, flagellates, protozoans, foraminiferans and other meiofauna) of this unusual deep-sea region. 
Because of the perennial ice coverage and extremely reduced primary productivity, the benthic environment of the central Arctic Ocean is extremely oligotrophic compared to other oceans. Phytoplankton production is limited by the shading effect of ice cover and restricted to the upper $100 \mathrm{~m}$ of the water column by a year-round halocline (ALEXANDER, 1980; WHEELER et al., 1996). However the ice acts as a substrate for ice algae, which form mats under the ice and contribute, on average, $57 \%$ of the entire primary production in the central Arctic Ocean (GossELIN et al., 1997). Because of particle degradation during sinking and high grazing pressure (WASSMANN et al., 1991; WHEELER et al., 1996) only a small fraction of organic matter from primary production reaches the deep-sea floor.

Results from benthic investigations conducted during the expedition "ARCTIC OCEAN 96" with the Swedish ice-breaker ODEN in summer 1996 on the central Arctic Lomonosov Ridge region showed very low levels of organic matter input and very low abundances of benthic organisms. The results indicated, this part of the Arctic Ocean is a "benthic desert" (Soltwedel and Schewe, 1998; Schewe and Soltwedel, 1999). However, the Lomonosov Ridge acts as a benthic and oceanographic boundary area, with partially enhanced ice crushing and a resulting locally enhanced primary production. Also, lateral input of autochthonous marine and allochthonous terrigenous organic matter provides carbon efflux from the Siberian continental shelf into the central Arctic (STEIN, 1996).

In contrast, in the area of the Alpha Ridge there is a re-circulating system of strong icecoverage and water masses (the Beaufort Gyre), which probably inhibits a current-driven lateral input of particulate organic matter from the surrounding shelf regions. Because areas with open surface waters are rare primary production is limited, so this region would be expected to be even more oligotrophic. It is hypothesised that the expected strongly limited input of particulate organic matter in the benthic environment of the Alpha Ridge region will result in low sediment-bound pigment values and extremely low organism densities and biomass in the sediments.

\section{Material and Methods}

\subsection{Area of Investigation}

The Alpha Ridge belongs to the Amerasian part of the Arctic Ocean, which divides this region into the Makarov and Canada Basins (Fig. 1). While the Alpha Ridge rises to 1,200 m water depth, the adjacent basins are more than 3,000 $\mathrm{m}$ deep. The Lomonosov Ridge, rising to less than 1,000 $\mathrm{m}$ water depth, is connected to the Makarov Basin to the south and represents the border of the Eurasian part of the Arctic Mediterranean.

While the Eurasian Basin and the Lomonosov Ridge are well supplied by Atlantic water masses, only a small amount of these waters periodically pass over the Lomonosov Ridge to flow into the Makarov Basin (AAGAARD, 1981). The target area itself is mainly provided by waters of Pacific origin, flowing into the Arctic Ocean via the Bering Street (SwIFT et al., 1997; Pivovarov, in prep.).

Whereas the Eurasian Basin is strongly influenced by the Transpolar Ice Drift, the Amerasian Basin is predominantly a re-circulating system (Fig. 2). The latter basin is covered by a heavy perennial ice coverage, mainly created by the dominating Beaufort Gyre, with ice formed in the Beaufort and the Chukchi Sea (GoRdienko and LaKTIONOv, 1969; COLONY and Thorndike, 1984). This ice is retained for a long time in this region, with average ice-age of $16 \mathrm{y}$, and the average thickness of ice floes, $4-5 \mathrm{~m}$.

In contrast, ice transported within the Transpolar Drift requires only 2-5 y for a passage from the areas of origin (East Siberian Sea, Laptev and Kara Sea) via the North Pole to the Fram Strait (KöRNER, 1973), resulting in clearly reduced ice thickness. This ice transported by the Transpolar Drift into central Arctic regions is loaded with large amounts of terrigenous organic and inorganic material from the shelf areas (NÜRNBERG et al., 1994). 


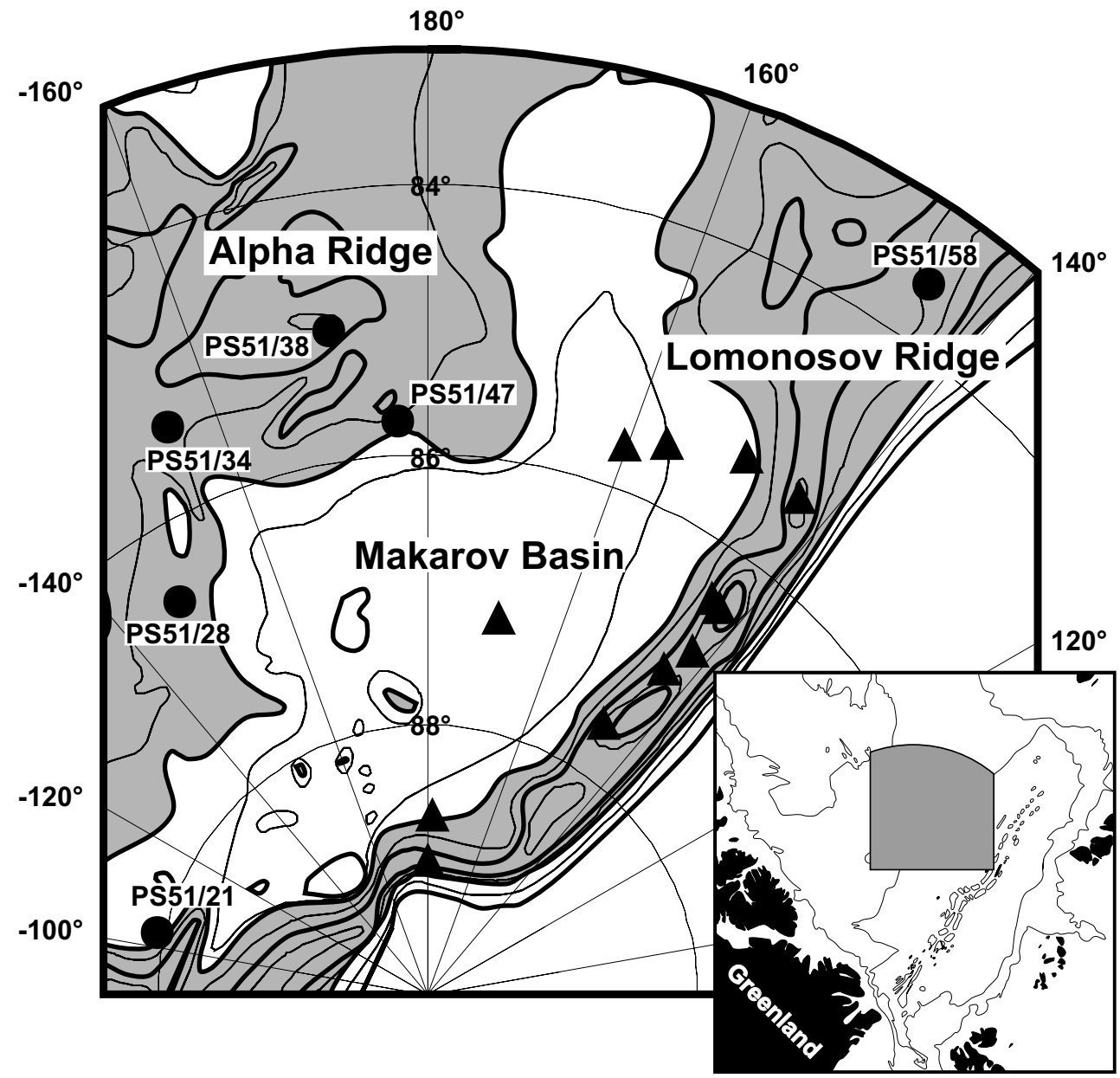

Figure 1. Sampling stations in the Alpha Ridge region, the Makarov Basin and on the Lomonosov Ridge during the expedition ARK XIV/1a in summer 1998 (labelled dots), plus stations already sampled during the expedition "ARCTIC OCEAN '96" (SCHEwE and SolTwEDEL, 1999) in summer 1996 (triangles).

\subsection{Sampling and Sample Processing}

Sediments were sampled during the expedition ARK-XIV/1a with the German research ice-breaker RV POLARSTERN in summer 1998. A total of six benthic stations were visited (Table 1). Four stations were located on the Alpha Ridge in water depths between 1,470 m and 3,130 m. In order to extend a set of stations already visited in 1996 (Soltwedel and Schewe, 1998; Schewe and Soltwedel, 1999) two additional stations were sampled in the deep Makarov Basin (Sta. PS51/21; $3170 \mathrm{~m}$ ) and on the Lomonosov Ridge crest (Sta. PS 51/58; 1,270 m).

Virtually undisturbed samples were taken using a multicorer (MUC) (BARNETT et al., 1984). This gear was equipped with an online video system, which provided the opportunity of semi-targeted sampling and visual inspection of the sampling area. Owing to limited ship time generally only one MUC haul was performed per sampling site. Oxygen content of the sediment overlying water from three MUC cores was determined by a WINKLER-titration. 


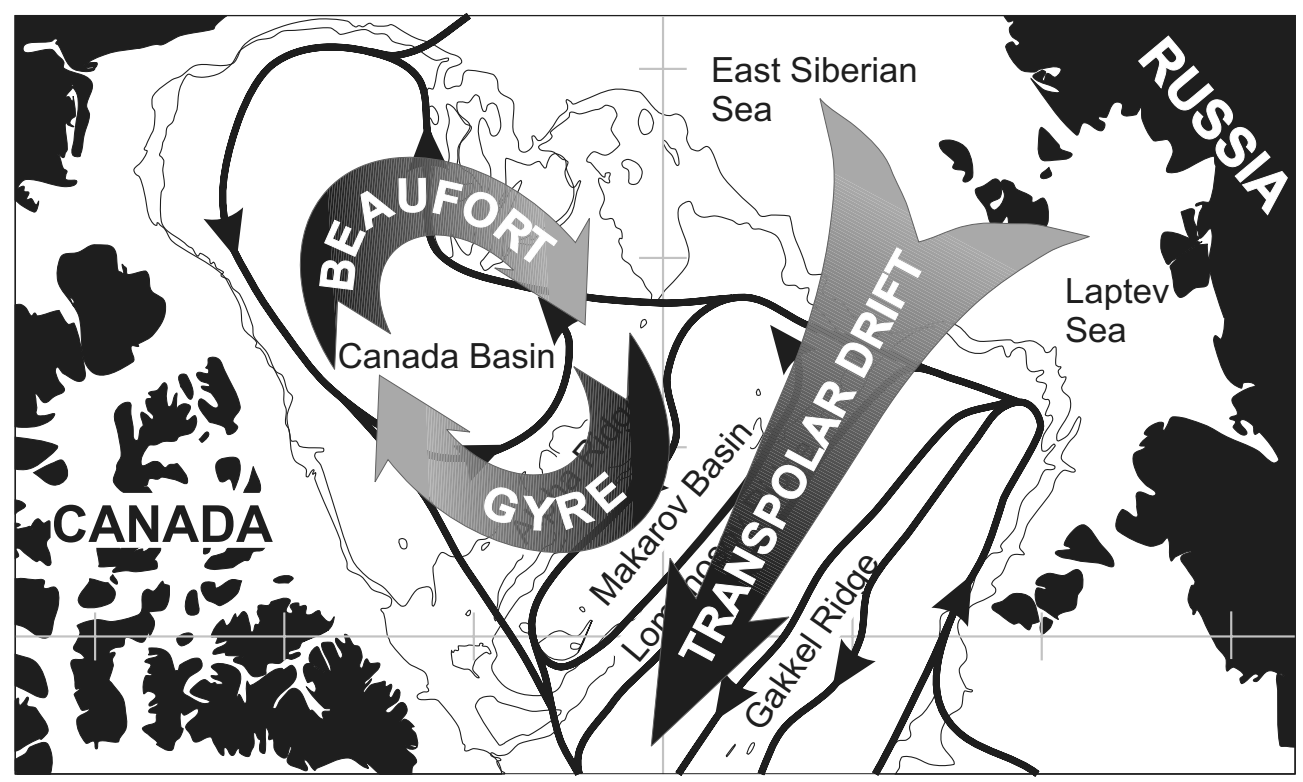

Figure 2. Sea-ice drift patterns in the Arctic Ocean.

A series of sediment samples were taken for investigating various abiotic and biotic parameters commonly used in ecological studies of the deep-sea benthos. The uppermost five centimetres of each sediment core were sub-sampled because the majority of deep-sea meiobenthos generally inhabits the uppermost $5 \mathrm{~cm}$ of the sediment (THIEL, 1983). Disposable syringes $(5 \mathrm{ml}$ and $20 \mathrm{ml}$ ) with cut-off anterior ends were used for subsampling, taking single sediment volumes of $1.17 \mathrm{~cm}^{3}$ and $3.24 \mathrm{~cm}^{3}$, respectively. Three pseudo-replicates (VENRICK, 1971) from different MUC tubes of one haul were taken for each parameter investigated. Samples were either processed directly on board or fixed with $4 \%$ formalin or stored at $-20{ }^{\circ} \mathrm{C}$ for later analyses at the home laboratory.

To estimate flux of phytodetritus to the seafloor, sediment-bound chloroplastic pigments were determined fluorometrically from sediments subsampled by small syringes, applying a method already described in SOLTWEDEL and SCHEWE (1998).

Sediments for the quantitative determination of meiobenthic organisms were taken by three larger syringes $(\varnothing \sim 2.5 \mathrm{~cm})$, covering altogether a sediment surface of $\sim 10 \mathrm{~cm}^{2}$ as recommended by FLEEGER et al. (1988). The sediments were stained with Rose Bengal and fractionated by wet sieving into five size-classes (500, 250, 125, 65 and $32 \mu \mathrm{m})$. Sorting and counting of each fraction was done in Bogorov dishes under a low power stereo microscope. Organisms were identified to the major taxa Foraminifera, Nematoda and Harpacticoidea/nauplii. All other taxa, appeared in small numbers (e.g. Cnidaria, Turbellaria, Gastrotricha, Kinorhyncha, Bivalvia and Polychaeta) and were pooled into one category,

Table 1. Station data for the RV POLARSTERN expedition "ARK XIV/1a"

\begin{tabular}{lccccl}
\hline Date & Station & Latitude & Longitude & Water Depth [m] & \multicolumn{1}{c}{ Location } \\
\hline 10. 07. 98 & PS 51/21 & $87,561 \mathrm{~N}$ & $102,595 \mathrm{~W}$ & 3170 & Makarov Basin \\
13. 07.98 & PS 51/28 & $86,333 \mathrm{~N}$ & $147,386 \mathrm{~W}$ & 3130 & Alpha Ridge rise \\
15. 07. 98 & PS 51/34 & $85,223 \mathrm{~N}$ & $155,240 \mathrm{~W}$ & 2070 & Alpha Ridge slope \\
16.07.98 & PS 51/38 & $85,015 \mathrm{~N}$ & $171,270 \mathrm{~W}$ & 1470 & Alpha Ridge crest \\
18.07.98 & PS 51/47 & $85,450 \mathrm{~N}$ & $176,560 \mathrm{~W}$ & 2450 & Alpha Ridge slope \\
21.07.98 & PS 51/58 & $83,335 \mathrm{~N}$ & $144,477 \mathrm{E}$ & 1270 & Lomonosov Ridge crest \\
\hline
\end{tabular}


"others". Foraminifera generally dominated the total meiobenthos and were classified into three morphological groups: rhizopoda with calcareous shells (e.g. Miliolina, Rotaliina), chitinous rhizopoda (Allogromiina) and agglutinating rhizopoda (Textulariina). Frequently appearing foraminiferans, were determined to genus level. The limitations of Rose Bengal staining of foraminiferal organisms is well known (BERNHARD, 1989; CORLISS and EMERSON, 1990) and was taken into account. Only those specimens were counted in which the tests and stercomata (faecal pellets) had a fresh appearance and at least some stained protoplasm was present.

Biomass determinations of meiofaunal organisms were carried out exclusively for nematodes, the most abundant metazoan meiofauna group. Nematode lengths (excluding filiform tails) and widths were measured by a semi-automated image analysis system (analySIS ${ }^{\circledR}$ ). Nematoda volumes and biomasses (wet weights) were calculated using equations given by ANDRASSY (1956). Nematoda wet weights were finally converted to carbon biomass, assuming that $100 \%$ wet weight corresponds to $12.4 \%$ carbon weight (JENSEN, 1984).

Densities of sediment-inhabiting bacteria were determined by epifluorescence microscopy, after staining with Acridine Orange (MEYER-REIL, 1983). Each calculated value represents the mean of 40 grid counts of a single filtered station sample (one $5 \mathrm{ml}$ syringe). Volumetric measurements of 60 bacterial cells per filter were conducted with the New Porton grid as described by GROSSMANN and ReICHHARD

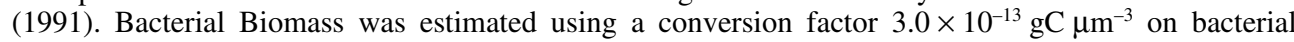
volumes (BøRsheIM et al., 1990).

Bacteria and also Protozoa (e.g. foraminiferans) are able to use hydrolytic enzymes for cleaving organic macromolecules (MEYER-REIL and KöSTER, 1991; BERNHARD et al., 1995). Esterases in particular are involved in the primary decomposition of organic matter. The potential activity of such enzymes was measured offering the fluorogenic substrate fluorescein-di-acetate (FDA) applying the method given by MEYER-REIL (1992).

Phospholipids, indicating cell wall components of living organisms, were analysed to quantify the total microbial biomass (TMB) (for details see Soltwedel and Schewe, 1998). The size of the subsamples allowed this assay to cover the whole size-range of organisms, from bacteria up to small metazoans (DobBS and FindLAY, 1993).

\section{Results}

\subsection{Parameters Describing Environmental Conditions}

Table 2 summarises environmental data for stations investigated. Reduced oxygen contents in the Makarov Basin, and on the Alpha Ridge rise, probably indicate different bottom near water masses compared to stations located south of $86^{\circ} \mathrm{N}$ on the shallower area of the Alpha Ridge, which shows clearly enhanced oxygen contents. Both slightly enhanced $\mathrm{O}_{2-}$ content and higher water-temperature clearly separate the Lomonosov Ridge station PS 51/58 from all other stations investigated in this study.

Table 2. Environmental parameters: oxygen concentrations in the sediment overlying water and sediment-bound chloroplastic pigments (Chl $a$ : chlorophyll $a$, Phaeo.: phaeopigments, CPE: chloroplastic pigment equivalents)

\begin{tabular}{|c|c|c|c|c|c|}
\hline Station & $\begin{array}{c}\text { Water Depth } \\
{[\mathrm{m}]}\end{array}$ & $\begin{array}{c}\text { Oxygen Water } \\
{\left[\mathrm{mg} \mathrm{O}_{2} / \mathrm{l}\right]}\end{array}$ & $\begin{array}{c}\text { Chl } a \\
{\left[\mu \mathrm{g} \cdot \mathbf{c m}^{-3}\right]}\end{array}$ & $\begin{array}{c}\text { Phaeo. } \\
{\left[\mu \mathrm{g} \cdot \mathbf{c m}^{-3}\right]}\end{array}$ & $\begin{array}{c}\text { CPE } \\
{\left[\mu \mathrm{g} \cdot \mathbf{c m}^{-3}\right]}\end{array}$ \\
\hline PS $51 / 21$ & 3170 & 8.96 & 0.036 & 0.139 & 0.175 \\
\hline PS $51 / 28$ & 3130 & 8.96 & 0.006 & 0.102 & 0.108 \\
\hline PS $51 / 34$ & 2070 & 9.95 & 0.028 & 0.136 & 0.164 \\
\hline PS $51 / 38$ & 1470 & 10.10 & 0.026 & 0.167 & 0.193 \\
\hline PS $51 / 47$ & 2450 & 10.01 & 0.021 & 0.159 & 0.180 \\
\hline PS $51 / 58$ & 1270 & 10.37 & 0.067 & 0.403 & 0.470 \\
\hline
\end{tabular}


Sediment-bound chloroplastic pigments were analysed to estimate the input of particulate organic matter to the sea floor from different sources of primary production (i.e. sea ice, euphotic zone). Chloroplastic pigments in the uppermost centimetre of the sediments generally decreased with increasing water depth. Highest concentrations were found at the Lomonosov Ridge station PS51/58 $\left.\left(0.07 \pm 0.05 \mu \mathrm{g} \mathrm{Chl} a \mathrm{~cm}^{-3} ; 0.40 \pm 0.15 \mu \mathrm{g} \mathrm{CPE} \mathrm{cm}\right)^{-3}\right)$. In comparable water depths on the Alpha Ridge, highest pigment concentrations at station PS 51/38 were 2-3 times lower $\left(0.03 \pm 0 \mu \mathrm{g} \mathrm{Chl} a \mathrm{~cm}^{-3} ; 0.17 \pm 0.04 \mu \mathrm{g} \mathrm{CPE} \mathrm{cm}{ }^{-3}\right)$ than those measured on the Lomonosov Ridge crest. Lowest concentrations of chloroplastic pigments $\left(0.01 \pm 0 \mu \mathrm{g} \mathrm{Chl} a \mathrm{~cm}^{-3} ; 0.10 \pm 0.02 \mu \mathrm{g} \mathrm{CPE} \mathrm{cm}{ }^{-3}\right)$ were detected on the Alpha Ridge rise (Sta. PS51/28). The vertical distribution of sediment bound pigments (Fig. 3) shows very low concentrations of the degraded plant pigments (phaeopigments) $(<0.05 \mu \mathrm{g}$ phaeo $\mathrm{cm}^{-3}$ ) in the Alpha Ridge sediments deeper than one centimetre. In contrast, on the Lomonosov Ridge deeper sediment layers showed comparably high pigment concentrations $\left(>0.24 \mu \mathrm{g}\right.$ phaeo $\left.\mathrm{cm}^{-3}\right)$. The lowest pigment concentration at the Lomonosov Ridge (at 3-4 cm sediment depth) was still higher than the highest surface concentration investigated on the Alpha Ridge station PS51/38.

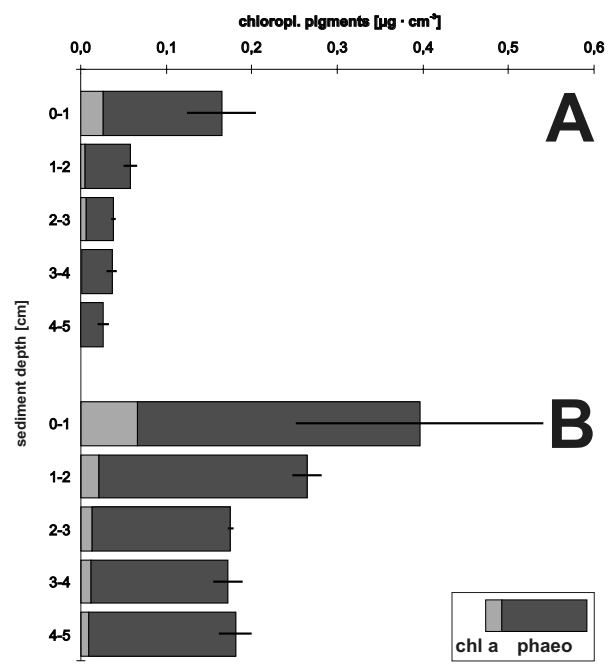

Figure 3. Vertical distribution of sediment-bound chloroplastic pigments at stations of A) the Alpha Ridge (PS51/38) and B) the Lomonosov Ridge (PS 51/58) crest stations.

\subsection{Bacterial Abundance, Biomass and Activity}

Bacterial numbers ranged between 1.5 and $4.8 \times 10^{8}$ cells $\mathrm{cm}^{-3}$ (Sta. PS51/34 and PS 51/58, respectively). Bacterial biomass generally mirrored bacterial density (Table 3). Values ranged between 5.86 and $14.30 \mu \mathrm{g} \mathrm{C} \mathrm{cm}^{-3}$ (for the same stations named above). In contrast, average bacterial volumes showed a slight (but non-significant) trend for larger organisms at deeper stations, with a maximum at Sta. PS51/34 $\left(0.22 \mu^{3}\right)$ and a minimum at Sta. PS 51/58 $\left(0.14 \mu \mathrm{m}^{3}\right)$. Bacterial esterase activities (FDA) followed a gradient with water depth, exhibiting lowest activity at one of the deepest stations (PS51/28; $0.36 \pm 0.03 \mathrm{nmol} / \mathrm{cm}^{3} \mathrm{~h}^{-1}$ ) and highest activities at the Lomonosov Ridge crest station $\left(\mathrm{PS} 51 / 58 ; 1.64 \pm 0.09 \mathrm{nmol} / \mathrm{cm}^{3} \mathrm{~h}^{-1}\right)$. 
Table 3. Bacterial numbers (BN), biomass (BB) and volumes (BV) as well as total microbial biomass (TMB) from phospholipid determinations and exoenzymatic activities (FDA) in the uppermost centimetre of the sediments.

\begin{tabular}{|c|c|c|c|c|c|}
\hline Station & $\begin{array}{c}\mathbf{B B} \\
{\left[\mu \mathrm{gC} \cdot \mathbf{c m}^{-3}\right]}\end{array}$ & $\begin{array}{c}\mathbf{B N} \\
{\left[\cdot 10^{8} \mathrm{~cm}^{-3}\right]}\end{array}$ & $\begin{array}{c}\mathbf{B V} \\
{\left[\mu \mathbf{m}^{3}\right]}\end{array}$ & $\begin{array}{c}\text { TMB } \\
{\left[\mu \mathrm{gC} \cdot \mathbf{c m}^{-3}\right]}\end{array}$ & $\begin{array}{c}\text { FDA } \\
{\left[\mathrm{nmol} / \mathrm{ml} \cdot \mathbf{h}^{-1}\right]}\end{array}$ \\
\hline PS 51/21 & 13.36 & 3.59 & 0.21 & 30.41 & 0.49 \\
\hline PS 51/28 & 9.20 & 2.61 & 0.19 & 25.47 & 0.36 \\
\hline PS 51/34 & 5.86 & 1.54 & 0.22 & 39.59 & 0.68 \\
\hline PS 51/38 & 14.64 & 4.22 & 0.19 & 21.90 & 0.76 \\
\hline PS 51/47 & 6.50 & 1.84 & 0.19 & 43.35 & 0.74 \\
\hline PS $51 / 58$ & 14.30 & 4.85 & 0.14 & 83.38 & 1.64 \\
\hline
\end{tabular}

\subsection{Meiobenthic Distribution Patterns}

Except at the Lomonosov Ridge station PS51/58, the vertical distribution of meiofauna within the upper two centimetres of the sediment column showed only slight differences between the stations investigated. Most specimens on the Alpha Ridge occurred in the top centimetre $(>70 \%)$; more than $90 \%$ of meiofauna organisms being found in the uppermost 2 centimetres (specimens in $0-5 \mathrm{~cm}=100 \%$ ). Stations in the Makarov Basin and at the Lomonosov Ridge crest (PS 51/21 and PS 51/58, respectively) exhibited lower relative proportions in the top centimetre $(61.2 \%$ and $65.8 \%$, respectively). The smoothest gradient was found at the Lomonosov Ridge crest station PS 51/58. Almost 35\% of meiofaunal organisms occurred in sediments deeper than $1 \mathrm{~cm}$. Fig. 4 shows this cumulative frequency of total meiofauna down to a sediment depth of $5 \mathrm{~cm}$.

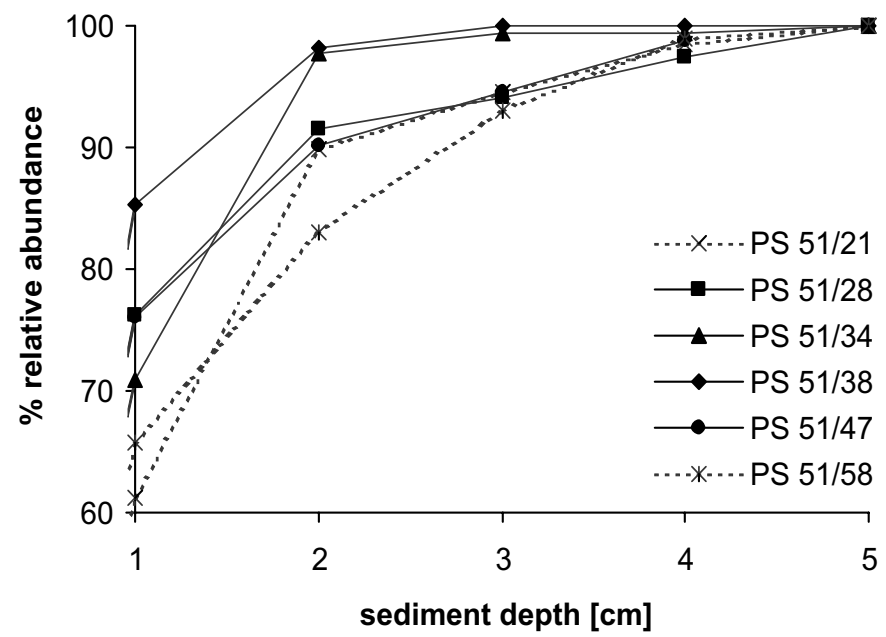

Figure 4. Cumulative curves showing relative proportions of meiofauna organisms in the uppermost $5 \mathrm{~cm}$ of the sediment column. 
I. SCHEWE

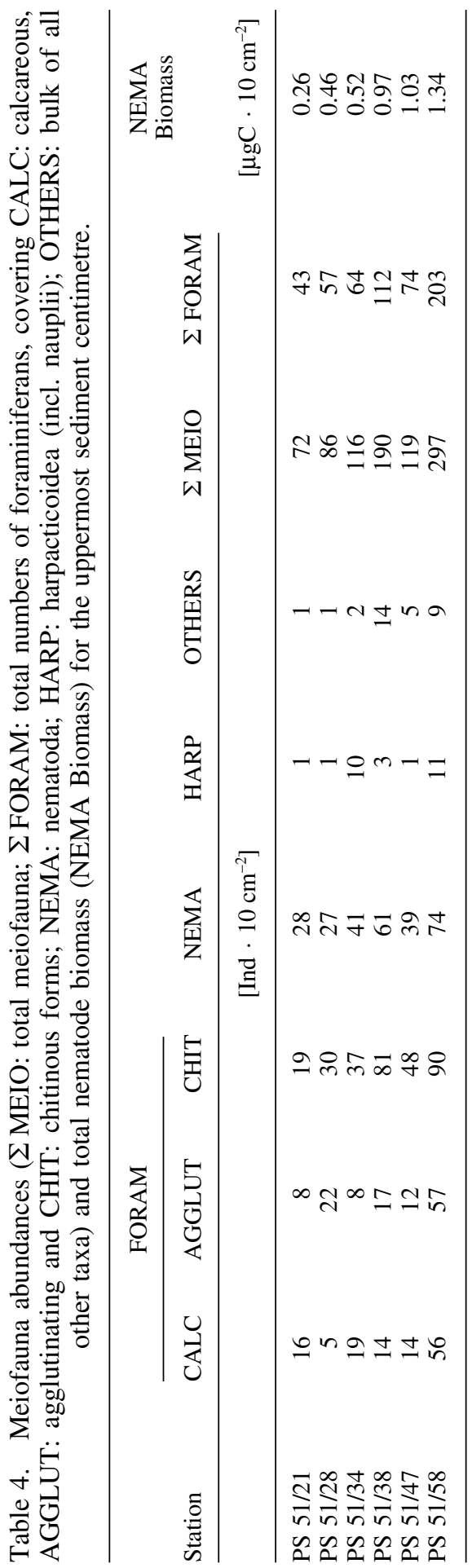


Table 4 presents meiobenthic densities at stations investigated in this study. Abundances in the Alpha Ridge region were extremely low (128 \pm 44 individuals $\left.10 \mathrm{~cm}^{-2}\right)$, reflecting the extreme remoteness of this region, isolated from enhanced fluxes of POM as confirmed by the data of sediment bound CPE (see above). Nevertheless species abundances generally followed a depth gradient and showed decreasing values with increasing water depth. Lowest meiobenthic abundances (72 \pm 17 individuals $10 \mathrm{~cm}^{-2}$ ) were found at station PS 51/21 in the deep Makarov Basin, whereas on the Lomonosov Ridge crest (PS51/38), there were comparable high abundances $\left(297 \pm 82\right.$ individuals $\left.10 \mathrm{~cm}^{-2}\right)$.

The meiofauna community was dominated by foraminiferans. They showed the lowest relative proportion ( $50 \%$ ) on the Lomonosov Ridge crest (PS 51/58), increasing up to 61\% at Alpha Ridge station PS 51/47. Except for Sta. PS 51/21, Allogromiina generally comprised more than half of the foraminiferal community. Chitinous foraminifera generally dominated over agglutinating and calcareous foraminiferans. Relative proportions of agglutinating and calcareous foraminiferans were rather variable and usually showed no trend.

Nematodes were the second most abundant group. They appeared at all stations and in all sediment layers investigated and their relative proportion was approximately $35 \%$ of the total meiofauna. Harpacticoidea were also found at all stations, but never occurred in sediments deeper than $3 \mathrm{~cm}$. Their relative proportion was well below 10\%. All other metazoan taxa (e.g. Cnidaria, Turbellaria, Gastrotricha, Kinorhyncha, Bivalvia and Polychaeta) showed extremely low densities and very patchy distribution patterns. The highest number of different metazoan taxa was found at the Lomonosov Ridge station PS 55/58.

\subsection{Size Structure of the Meiofauna Community}

The size structure of meiofauna organisms was characterised by generally high relative proportions $(63-82 \%)$ retained by sieves with mesh-sizes of $32 \mu \mathrm{m}$ and $64 \mu \mathrm{m}$ (Fig. 5). No regional differences in meiobenthic size spectra were found within the limited set of data. However, the integration of these data into a larger data set obtained during an expedition in 1996 (SCHEwE and SolTwEDEL, 1999) allowed the identification of regional differences in meiofauna body size with slightly higher proportions of smallest organisms $(32-63 \mu \mathrm{m})$ on the ridges compared with the Makarov Basin (see discussion).

\subsection{Nematode Biomasses}

Total nematode biomass significantly decreased with increasing water-depth and generally followed decreasing abundances (Table 4). Accordingly, lowest biomass was found in the deep Makarov Basin at station PS 51/21 (0.027 $\mu \mathrm{g} \mathrm{C})$ and highest biomass on top of the Alpha Ridge (PS 51/38; $0.302 \mu \mathrm{g} \mathrm{C}$ ). Restricted to the Alpha Ridge region highest biomass, and also abundances of nematoda $\left(3.02 \mu \mathrm{g} \mathrm{C} ; 61\right.$ individuals $\left.10 \mathrm{~cm}^{-2}\right)$, were found at the shallowest station, PS55/38.

\subsection{Biomass in Different Compartments of Small Benthic Biota}

The highest TMB estimated from phospholipid analyses was found in sediments at the Lomonosov Ridge crest station PS 51/58 $\left(83.38 \pm 17.99 \mu \mathrm{g} \mathrm{C} \mathrm{cm}^{-3}\right)$ (Table 5). Intermediate values were measured on the Alpha Ridge slope and lowest biomass of the bulked small sediment inhabiting organisms $\left(21.90 \pm 22.44 \mu \mathrm{g} \mathrm{C} \mathrm{cm}^{-3}\right)$ was found on the Alpha Ridge crest (Sta. PS 51/38).

Assuming that the determination of TMB registers the bulk of sediment-inhabiting organisms (bacteria, fungi, yeast, protozoans and small metazoans), it was of special interest to 


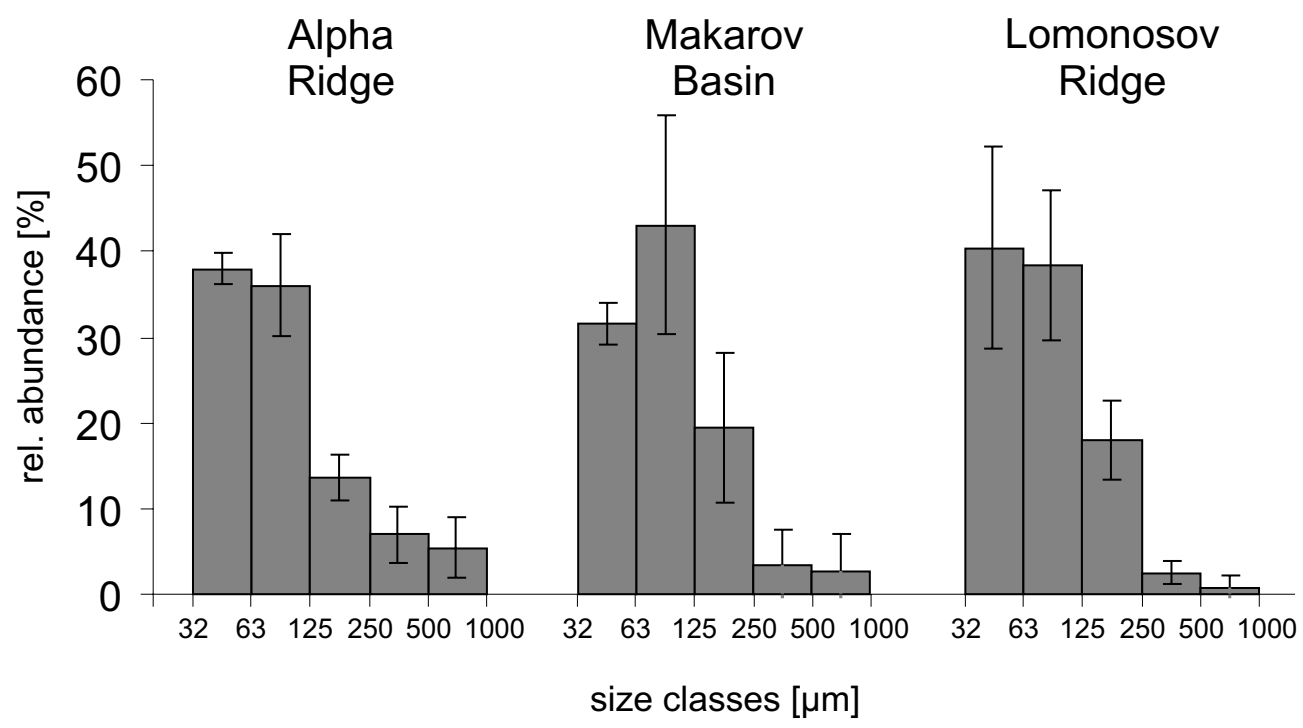

Figure 5. Relative abundance of meiofauna organisms (including foraminifera) in different size-classes for individual regions.

quantify the proportions of different organism types or size classes (meiofauna, nanofauna and bacteria) on total microbial biomass.

A comparison of biomass data from the various compartments showed that up to $66 \%$ (average: $32 \%$ ) of total biomass per station belongs to bacterial biomass (BB) and only $0.4 \%$ (average $0.2 \%$ ) were held by nematodes. As nematodes on average comprise about $83 \%$ of the total metazoan meiofauna the relative proportion of the total metazoan meiofauna biomass (MMB) will probably be well below 1\%. Thus 31-84\% (average: 67\%) of the TMB belongs to the residual biomass (RB), represented by organisms of nanofaunal size (i.e. protozoans, flagellates, ciliates, fungi and yeasts). Whereas relative proportions of nematode biomass show a slight, but not significant decline with decreasing water depth, such a trend was not detected in bacterial and 'residual' biomass. However, these calculations can only give a rough idea about the real proportions of organism compartments. In this connection it is important to note that nematode and bacterial biomasses were determined by

Table 5. Absolute biomass values and relative proportions in various compartments of the benthic community (TMB: total microbial biomass; BB: bacterial biomass; NB: nematode biomass; RB: residual biomass) for the uppermost centimetre of the sediments.

\begin{tabular}{|c|c|c|c|c|c|c|c|}
\hline \multirow[t]{2}{*}{ Station } & TMB & $\mathrm{BB}$ & NB & $\mathrm{RB}$ & \multirow[t]{2}{*}{$\% \mathrm{BB}$} & \multirow[t]{2}{*}{$\% \mathrm{NB}$} & \multirow[t]{2}{*}{$\% \mathrm{RB}$} \\
\hline & \multicolumn{4}{|c|}{$\left[\mu \mathrm{gC} \cdot \mathrm{cm}^{-3}\right]$} & & & \\
\hline PS $51 / 21$ & 30.41 & 13.36 & 0.02 & 17.04 & 43.92 & 0.05 & 56.02 \\
\hline PS $51 / 28$ & 25.47 & 9.20 & 0.02 & 16.25 & 36.12 & 0.10 & 63.78 \\
\hline PS $51 / 34$ & 39.59 & 5.86 & 0.06 & 33.67 & 14.79 & 0.15 & 85.06 \\
\hline PS $51 / 38$ & 21.90 & 14.64 & 0.09 & 7.18 & 66.83 & 0.41 & 32.76 \\
\hline PS $51 / 47$ & 43.35 & 6.50 & 0.21 & 36.64 & 14.99 & 0.49 & 84.52 \\
\hline PS $51 / 58$ & 83.38 & 14.30 & 0.13 & 68.96 & 17.15 & 0.16 & 82.70 \\
\hline
\end{tabular}


volumetric measurements whereas phospholipids represents cell surfaces, which may overemphasise the bacterial biomass proportion (RAJENDRAN et al., 1992).

\subsection{Correlations between Determined Parameters}

A SPEARMAN rank-correlation was performed with selected environmental parameters representing hydrostatic pressure and food availability (i.e. water depth and chloroplastic pigments), biochemically determined activity and biomass parameters (i.e. bacterial esterase activity $=$ FDA and phospholipids $=$ TMB), as well as bacterial numbers/biomass and meiofaunal abundance (Fig. 6). Bacterial esterase activities and meiobenthic abundance (foraminifera, metazoa) correlated significantly with water depth, esterase activity showing a significant correlation $(\mathrm{p}=0.018)$, and foraminiferal and metazoan abundances a highly significant $(p=0.004)$ correlation. Meiobenthic abundances also correlated highly significant $(\mathrm{p}=0.004)$ with bacterial activity and significantly $(\mathrm{p}=0.04)$ with chloroplastic pigment equivalents $(\mathrm{CPE})$. A significant correlation $(\mathrm{p}=0.018)$ was found between foraminiferal and metazoan abundances. Bacterial activities showed a strong coupling to the occurrence of phytodetritus (food availability). Potential esterase activity was highly significantly cor-

\begin{tabular}{|c|c|c|c|c|c|c|c|c|c|}
\hline & DEPTH & CHL A & CPE & FDA & TMB & BB & BN & FORAM & META \\
\hline DEPTH & -- & & & & & & & & \\
\hline CHL A & $\begin{array}{c}-0,371 \\
p=0,800\end{array}$ & -- & & & & & & & \\
\hline CPE & $\begin{array}{c}-0,714 \\
p=0,110\end{array}$ & $\begin{array}{c}0,942 \\
p=0,004\end{array}$ & -- & & & & & & \\
\hline FDA & $\begin{array}{c}-0,885 \\
p=0,018\end{array}$ & $\begin{array}{c}0,485 \\
p=0,328\end{array}$ & $\begin{array}{c}0,542 \\
p=0,265\end{array}$ & -- & & & & & \\
\hline TMB & $\begin{array}{c}-0,314 \\
p=0,544\end{array}$ & $\begin{array}{c}0,428 \\
p=0,396\end{array}$ & $\begin{array}{c}0,371 \\
p=0,468\end{array}$ & $\begin{array}{c}0,485 \\
p=0,328\end{array}$ & -- & & & & \\
\hline BB & $\begin{array}{c}-0,371 \\
p=0,468\end{array}$ & $\begin{array}{c}0,485 \\
p=0,328\end{array}$ & $\begin{array}{c}0,657 \\
p=0,156\end{array}$ & $\begin{array}{c}0,314 \\
p=0,544\end{array}$ & $\begin{array}{c}-0,314 \\
p=0,544\end{array}$ & -- & & & \\
\hline BN & $\begin{array}{c}-0,428 \\
p=0,396\end{array}$ & $\begin{array}{c}0,542 \\
p=0,265\end{array}$ & $\begin{array}{c}0,714 \\
p=0,110\end{array}$ & $\begin{array}{c}0,485 \\
p=0,328\end{array}$ & $\begin{array}{c}-0,028 \\
p=0,957\end{array}$ & $\begin{array}{c}0,942 \\
p=0,004\end{array}$ & -- & & \\
\hline FORAM & $\begin{array}{c}-0,942 \\
p=0,004\end{array}$ & $\begin{array}{c}0,942 \\
p=0,004\end{array}$ & $\begin{array}{c}0,828 \\
p=0,04\end{array}$ & $\begin{array}{c}0,257 \\
p=0,622\end{array}$ & $\begin{array}{c}0,371 \\
p=0,468\end{array}$ & $\begin{array}{c}0,428 \\
p=0,396\end{array}$ & $\begin{array}{c}0,485 \\
p=0,328\end{array}$ & -- & \\
\hline META & $\begin{array}{c}-0,942 \\
p=0,004\end{array}$ & $\begin{array}{c}0,942 \\
p=0,004\end{array}$ & $\begin{array}{c}0,828 \\
p=0,04\end{array}$ & $\begin{array}{c}0,600 \\
p=0,207\end{array}$ & $\begin{array}{c}0,371 \\
p=0,468\end{array}$ & $\begin{array}{c}0,428 \\
p=0,396\end{array}$ & $\begin{array}{c}0,485 \\
p=0,328\end{array}$ & $\begin{array}{c}0,885 \\
p=0,018\end{array}$ & - \\
\hline
\end{tabular}

Figure 6. SPEARMAN rank-correlation matrix with the variables water-depth (DEPTH), sedimentbound chlorophyll $a$ (CHL A), chloroplastic pigment equivalents (CPE), bacterial esterase activity (FDA), total microbial biomass (TMB), bacterial biomass (BB) and numbers (BN) and meiofauna abundance (FORAM: foraminifera; META: metazoan meiofauna). Levels of significance - white: no correlation; hatched: $\mathrm{p}<0.05$; black: $\mathrm{p}<0.005$. 
related ( $\mathrm{p}=0.004)$ with CPE concentrations. A highly significant correlation $(\mathrm{p}=0.004)$ was found between bacterial numbers and bacterial biomasses.

\section{Discussion}

\subsection{Sedimentation of POM in the Central Arctic}

The deep-sea benthos is mainly fuelled by organic matter produced in the euphotic zone. This material generally reaches the sea floor in various stages of degradation (BILLETT et al., 1983) after passing through the pelagic food-web. Only about $10 \%$ of the primary production in the open oceans sinks to $150 \mathrm{~m}$, and only about $10 \%$ of this remaining material reaches the deep-sea bottom at 4 to $5 \mathrm{~km}$ depth (ANGEL, 1984; WeFER, 1989). In Arctic regions of perennial ice cover, where primary production in the water column is highly limited, phytodetritus mainly consists of single cells slowly sinking to the seafloor. Aggregation of phytodetritus to larger flocs ('fluff'), as known e.g. from the NE Atlantic (RICE et al., 1986; THIEL et al., 1989), is most likely absent.

Because of long residence times in the Arctic pelagial, the largest part of phytodetritus reaching the arctic benthal is highly degraded by zooplankton and bacteria (GREBMEIER and BARRY, 1991). On the other hand, GossELIN et al. (1997) reported for the central Arctic Ocean a production from ice algae twice as high as that within the water column. Phytodetritus from ice-algal blooms may rapidly sink in detached mats, probably causing a patchy distribution of plant pigments, with enhanced concentrations of comparably fresh sediment bound chloroplastic pigments at the sea floor. But blooms are mostly restricted to areas were light can pass through the snow and ice.

The Amerasian Basin hosts a re-circulating system of ice and water masses (Beaufort Gyre). This system is largely decoupled from a significant lateral supply of organic matter. Although water masses in the Amerasian Basin have relatively high nutrient concentrations (SWIFT et al., 1997), primary production within the water column and a subsequent sedimentation of particulate organic matter $(\mathrm{POM})$ to the seafloor, as indicated by sedimentbound pigments, is extremely low, most probably because of shading effects of the heavy ice cover within the Beaufort Gyre. Areas of enhanced ice crushing, causing a reinforced release of ice algal mats, as known from the Lomonosov Ridge, are mostly missing in the Alpha Ridge region. This was reflected by the generally low pigment concentrations in the Alpha Ridge sediments.

A frontal system of Pacific and Atlantic water masses observed during the cruise over the Alpha Ridge slope (PIVOVAROv, in prep.), that might be expected to increase nutrients and stimulate primary production, was not reflected in enhanced sediment-bound pigment concentrations at the Alpha Ridge stations.

The low pigment concentrations on the sediment surface of the Alpha Ridge stations, and the horizontal distribution patterns of plant pigments within the sediment columns, confirm very low input of organic matter within this region (Fig. 3). This becomes obvious when comparing the data with results from the Lomonosov Ridge stations (see also SolTwEDEL and SCHEWE, 1998). There was a comparable smooth decrease in chloroplastic pigments with increasing sediment depth at the Lomonosov Ridge crest stations. CPE concentrations from the deepest sediment layers investigated, were still higher than highest concentrations measured in the uppermost layers at Alpha Ridge stations.

Pigment concentrations in the Lomonosov Ridge region (station PS51/58), combined with stations investigated by SolTwEDEL and ScHEwE (1998), clearly exceeded those values determined at stations from the Alpha Ridge (Fig. 7A). Higher values at the Lomonosov Ridge are probably due to a generally enhanced primary production and detachment of ice-algae within patchy, ice-free areas caused by strong current driven ice floe movements and ice crushing 
(GORDIENKO and LAKTIONOv, 1969). Moreover, the Lomonosov Ridge region is strongly influenced by the transpolar drift, transporting huge amounts of inorganic and organic material (probably also including phytodetrital matter) from marginal shelf areas.

Conditions at the Lomonosov Ridge were already assessed as extremely oligotrophic (SOLTWEDEL and SCHEWE, 1998) compared with values reported from the marginal ice zone in the Fram Strait (SolTwedEl et al., 2000), from the Eurasian continental margin (PfanNKUCHE and THIEL, 1987; GRAHL, 1996) and especially from other, non-ice covered oceanic regions (Scheibe, 1990; PfannKuChe, 1992). However, CPE concentrations found at the Lomonosov Ridge were almost three times higher than those determined for the Alpha Ridge region. Thus the Alpha Ridge region is probably the most oligotrophic area of the world ocean.

Several authors have found in Arctic regions a general decrease of CPE with water depth (Pfannkuche and Thiel, 1987; Boetius and Damm, 1998; Soltwedel and Schewe, 1998). However, within the Alpha Ridge region a correlation between pigment concentrations and water depth was not detectable. Concentrations at shallower stations on the Alpha Ridge were in the same range as those found in the deep Makarov Basin. A patchy sedimentation of extremely low amounts of phytodetrital matter is most likely responsible for the lack of correlation between water depth and sediment-bound pigments. This emphasises the oligotrophic character of this area.

Apart from the hypothesis of a lateral input of phytodetritus from the highly productive shelf regions, the integration of the CPE data determined for station PS51/58 into a data set of Lomonosov Ridge crest stations (SolTwEDEL and SCHEWE, 1998) does not confirm a general northerly decrease of pigment concentrations (Fig. 7A). It rather seems that locally enhanced POM pulses are superimposed on a possibly existing gradient.

\subsection{Benthic Response to Sedimentation of POM}

A significant correlation between meiobenthic abundances (Foraminifera and Metazoa) and CPE suggests a direct dependency of meiobenthic organisms on the availability of POM as a food resource. However, although a highly significant correlation between the potential activity of esterase cleaving enzymes (FDA) and CPE demonstrates a strong coupling between the activity of bacteria and protozoans and the availability of utilisable phytodetritus, neither bacterial abundances and biomasses or total microbial biomasses showing any relationship with food availability (CPE). The activation of bacterial extracellular enzymatic activity in particular is one of the first responses to organic matter input (MEYER-REIL and KÖSTER, 1992; Boetius and Lochte, 1994). So it seems likely that the exoenzymatic reactions followed very recent sedimentation pulses (BoETius and Lochte, 1996; PfannKuCHE et al., 1999), and the high bacterial activities might be direct reactions to enhanced primary production during the Arctic summer.

However, a comparable increase in microbial biomass was not noticeable in the area of investigation. This is probably caused by slow physiological processes of nutrient utilisation, preceding cell growth (BoETIUS and LOCHTE, 1996). The method of sediment sampling provides only a snapshot registration of values, so it is supposed that a response to food pulses might be recognisable at a later date of sediment sampling.

The overall low flux of utilisable organic matter to the seafloor is also reflected in the vertical distribution of benthic organisms in the sediment column. Highest abundances were generally found at the sediment-water interface. The overall higher supply of organic matter in the Lomonosov Ridge area is mirrored by smoother gradients of small benthic organisms within the sediments (Fig. 4).

Compared to meiofauna numbers from the Lomonosov Ridge region (SCHEwE and SoLTWEDEL, 1999), a Mann-Whitney U-test confirmed significantly lower meiobenthic densities 

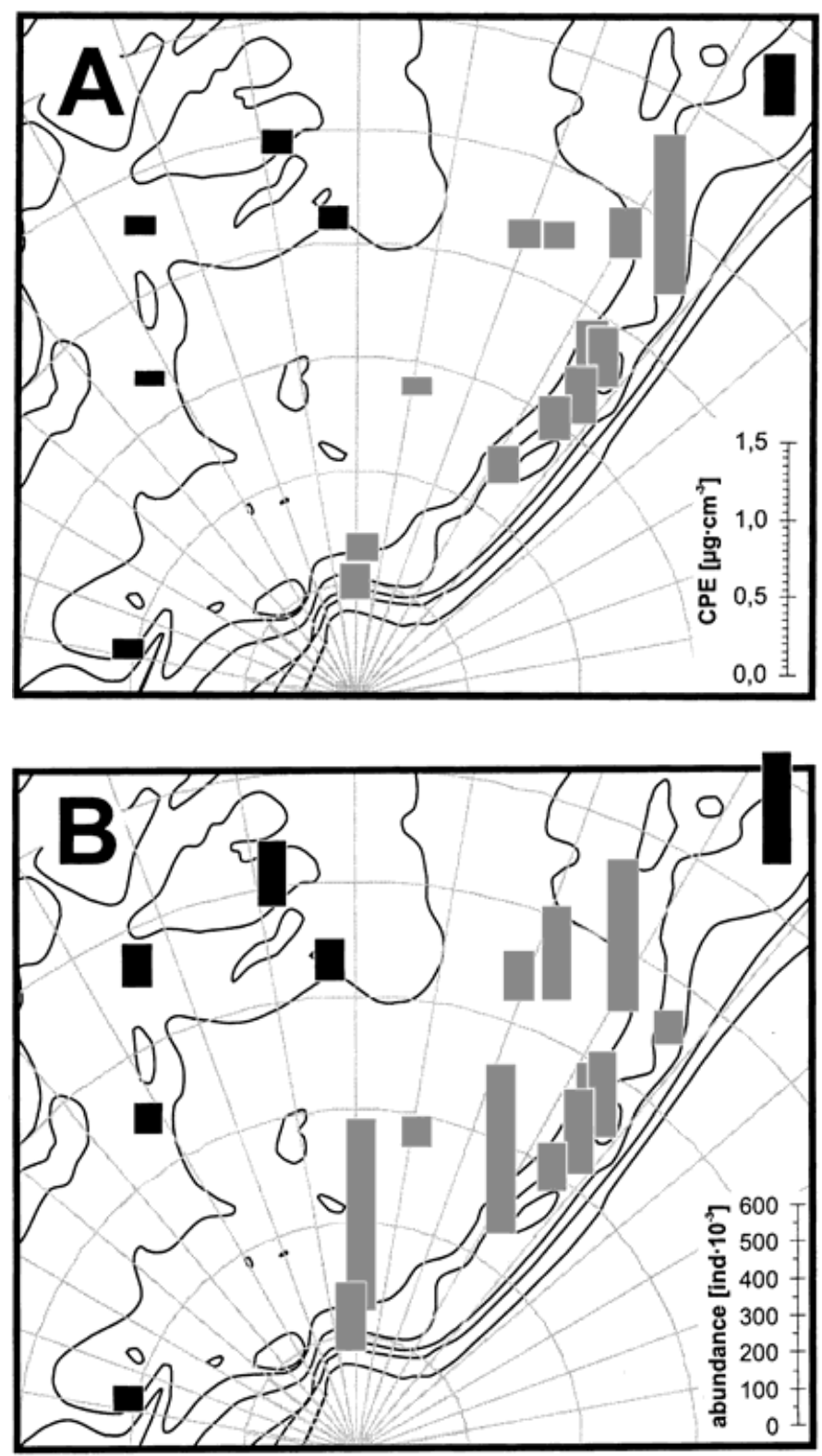

Figure 7. Chloroplastic pigment equivalents (A) and meiofauna abundances (B) in the uppermost centimetre of the sediments $(0-1 \mathrm{~cm})$; black columns: stations investigated during the expedition ARK XIV1a in 1998, grey columns: stations investigated during the expedition "ARCTIC OCEAN '96" 
$(\mathrm{p}=0.049)$ at Alpha Ridge stations (Fig. 7B). However, on the basis of pigment concentrations within the sediments from the different regions, meiobenthic densities as well as total microbial biomass, were higher than expected on the Alpha Ridge. On the other hand, low exoenzymatic activities at the Alpha Ridge better correspond with the low pigment concentrations from the same stations. The community of small-sized benthic organisms from the Alpha Ridge is obviously able to survive on an extremely reduced metabolic level, while maintaining comparably high organism abundances and biomass.

\subsection{Biomass in Various Compartments of the Small-Sized Benthic Organisms}

Arctic studies dealing with investigations on microbial organisms in bottom sediments are scarce. SoltwedEL and SCHEwE (1998) provide the only previous data from the central Arctic Ocean. Applying the same methods, they found generally lower proportions of BB to TMB (average 20\%) than those found in this study, which indicates a slightly higher importance of bacteria in the oligotrophic Alpha Ridge region.

The relative proportion of bacterial biomass (BB) to total microbial biomass was lowest at Sta. PS51/34 (15\%). One reason for these comparable low BB proportions might be an increased grazing pressure of protozoans, as indicated by a high proportion in residual biomass (RB) $(85 \%)$ at this particular station. It is commonly accepted that bacterial production is kept in balance by protozoan grazing (ELDRIDGE and JACKSON, 1992; Alonso et al., 2000).

Investigations from the northern Fram Strait (SOLTwEDEL et al., 2000) and from the European continental margin (Goban Spur, NE Atlantic), (Poremba and HopPe, 1995; PfanNKUCHE and SOLTWEDEL, 1998) showed higher relative proportions of BB than those presented in this study. Soltwedel et al. (2000) reported proportions of BB to vary between $33 \%$ and $57 \%$ (average: $48 \%$ ). BB proportions in north eastern Atlantic sediments ranged from $42 \%$ to $48 \%$ (average: $46 \%$ ) (PFANNKUCHE and SOLTWEDEL, 1998).

BoETIUS and DAMM (1998) reported a down-slope increase of relative BB proportions to a maximum of $50 \%$ down to a depth of $2,500 \mathrm{~m}$, followed by decrease again to about $20 \%$ at greater depths. Average proportion of BB on TMB was $36 \%$. In contrast, total bacterial biomass and $\mathrm{BB}$ proportions at stations investigated in this study showed large fluctuations unrelated to water-depth or food availability (phytodetritus) at the seafloor.

A comparison of bacterial biomass data from different oceanic regions (Table 6) shows generally lower average BB proportions in central Arctic regions compared to marginal polar regions or the NE-Atlantic. Absolute values for TMB, BB and also NB clearly decreased with a reduced availability of food as shown from the NE Atlantic via the marginal Arctic regions to the central Arctic regions and the extremely oligotrophic Alpha Ridge region.

\subsection{Meiobenthic Size Spectra}

Investigations of meiobenthic sieve-size distributions were performed to identify variabilities in meiobenthic size spectra in relation to the trophic character of individual regions. No significant trends were found within the data set compiled in this study. However, a comparison of these data with those given by Schewe and Soltwedel (1999) for the Lomonosov Ridge region clearly exhibited regional differences in meiobenthic size spectra (Fig. 5). These differences are particularly demonstrated by high proportions of the smallest organisms $(32-63 \mu \mathrm{m})$ in the Ridge regions compared to the lower proportions found in the deep Makarov Basin, probably reflecting water-depth dependency. Differences between the two ridges predominantly concern the larger size classes $(>125 \mu \mathrm{m})$. At Alpha Ridge stations the 


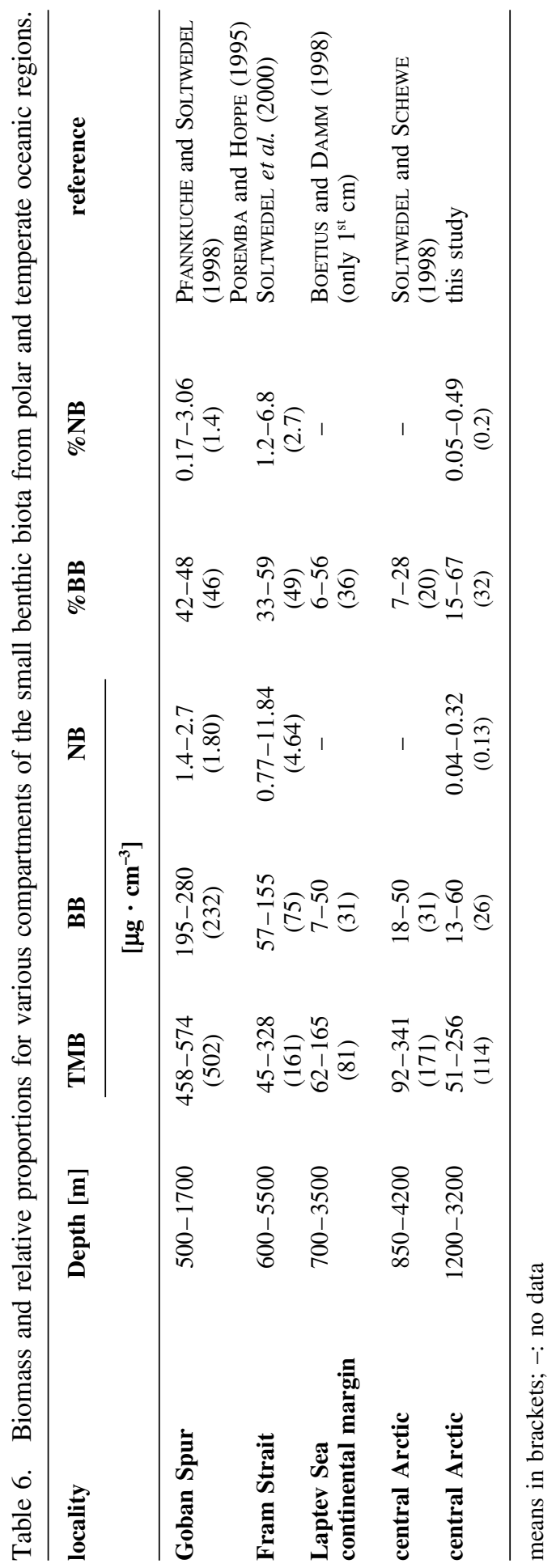


relative proportions of organisms with body size $>250 \mu \mathrm{m}$ are slightly (non-significantly) enhanced while the proportion in the size-class $125-250 \mu \mathrm{m}$ is lower compared with results from Lomonosov Ridge stations.

A comparison of size spectra examined in this study with those of the temperate NE Atlantic (SCHEIBE, 1990) and the western Pacific Ocean (ShIRAYAMA, 1983) reveal significant differences. Whereas meiobenthic communities of the central Arctic Ocean tend to dwarfism, being clearly dominated by small organisms $(32-125 \mu \mathrm{m})$, organisms with intermediate body size in non-ice covered regions generally dominate. In the North Atlantic the largest proportion of meiobenthic organisms are found in the size-class of $125-250 \mu \mathrm{m}$, whereas in the western Pacific deep sea the largest proportion of organisms appear to be even larger $(250-500 \mu \mathrm{m})$.

\section{Conclusions}

Because of the inaccessibility of the Alpha Ridge region there has been almost no information available on the abundance and biomass of benthic organisms from this part of the central Arctic Ocean. A compilation of results from expeditions into adjacent regions allows establishment of biogeographical distribution patterns in relation to hydrographic and geo-morphologic settings.

The extremely low availability of primary organic matter (as indicated by sediment-bound chloroplastic pigments) and very low microbial biomass and meiobenthic abundance characterise the Alpha Ridge region as probably the most oligotrophic region of the world ocean.

Spatially and temporary enhanced input of POM was detected on the Lomonosov Ridge, whereas in the Alpha Ridge region overall quantities and gradients of pigment concentrations within the sediments suggest constantly low sedimentation of primary organic matter.

\section{Acknowledgements}

I wish to thank the crew of the German research-ice-breaker "RV Polarstern" and the crew of the Russian nuclear-powered ice breaker "Artika" for dislodging us so often from the grasp of heavy pack ice and also all the scientists for their helpful support during the expedition "ARK XIV/1a". Special thanks to THOMAs SOLTwEDEL and two anonymous reviewers for their critical reviews and valuable comments on this paper.

This is publication no. awi-n10027 of the Alfred-Wegener-Institut für Polar- und Meeresforschung, Bremerhaven, Germany.

\section{References}

AagaARD, K., 1981: On the deep circulation in the Arctic Ocean. - Deep-Sea Res. 28: 251-268.

ALEXANDER, V., 1980: Interrelationships between the seasonal ice and biological regimes. - Cold Regions Science and Technology 2: 157-178.

Alonso, M. C., V. Rodriguez, J. Rodriguez and J. J. Borrego, 2000: Role of ciliates, flagellates and bacteriophages on the mortality of marine bacteria and on dissolved-DNA concentration in laboratory experimental systems. - J. Exp. Mar. Biol. Ecol. 244(2): 239-252.

ANDRASSY, I., 1956: The determination of volume and weight of nematodes. - Acta Zoologica (Hungarian Academy of Science) 2(1-3): 1-15.

ANGel, M. V., 1984: Detrital organic fluxes through pelagic ecosystems. - In: Flows of energy and materials in marine ecosystems: theory and practice. Edited by M. J. R. FASHAM, Plenum Press, New York: $475-516$.

BARNETT, P. R. O., J. WATSON and D. CONELLy, 1984: A multiple corer for taking virtually undisturbed samples from shelf, bathyal and abyssal sediments. - Oceanolog. Act. 7: 399-408. 
BERNHARD, J. M., 1989: The distribution of benthic foraminifera with respect to oxygene concentration and organic carbon levels in shallow-water Antarctic sediments. - Limnol. Oceanogr. 34: 1131-1141.

Bernhard, J. M., S. G. NewkiRK and S. S. Bowser, 1995: Towards a non-terminal viability assay for foraminiferan protists. - Journal of Eucariotic Microbiology 42: 357-367.

BilletT, D. S. M., R. S. LAMPiTT, and A. L. Rice, 1983: Seasonal sedimentation of phytoplankton to the deep-sea benthos. - Nature 302: 520-522.

Boetius, A. and E. DAmm, 1998: Benthic oxygen uptake, hydrolytic potentials and microbial biomass at the Arctic continental slope. - Deep-Sea Res. 45(2-3): 239-275.

BoEtius, A. and K. LochTE, 1994: Regulation of microbial enzymatic degradation of OM in deep-sea sediments. - Marine Ecology Progress Series 104: 299-307.

Boetius, A. and K. Lochte, 1996: Effect of organic enrichments on hydrolytic potentials and growth of bacteria in deep-sea sediments. - Mar. Ecol. Prog. Ser. 140(1-3): 239-250.

BøRShEIM, K. Y., G. BRATBAK and M. HELDAL, 1990: Enumeration and biomass estimation of planktonic bacteria and viruses by transmission electron microscopy. - Appl. Env. Microbiol. 56: 352-356.

Colony, R. and A. S. Thorndike, 1984: An estimate of the mean field of Arctic sea ice motion. - Journal of Geophysical Research 90(C6): 10623-10629.

Corliss, B. H. and S. EMERSON, 1990: Distribution of Rose Bengal stained deep-sea benthic Foraminifera from the Nova Scotian continental margin and Gulf of Maine. - Deep-Sea Res. 37(3A): $381-400$.

DobBs, F. C. and R. H. Findlay, 1993: Quantitative description of microbial communities using lipid analysis. - In: Handbook of methods in aquatic microbial ecology. Edited by P. F. KeMP, Lewis Publishers, Boca Raton, FL: 271-284.

EldRIDGE, P. M. and G. A. JACKSON, 1992: Benthic food web flows in the Santa Monica Basin estimated using inverse methodology. - In: Deep Sea Food Chains and the Global Carbon Cycle. Edited by G. T. ROWE and V. PARIENTE: 255-276.

Fleeger, J. W., D. Thistle and H. Thiel, 1988: Sampling Equipment. - In: Introduction to the Study of Meiofauna. Edited by R. P. Higgins and H. THIEL, Smithsonian Institution Press, Washington D.C. London: 115-125.

Gordienko, P. A. and A. F. Laktionov, 1969: Circulation and physics of the Arctic Basin Waters. In: Gordienko, P. A. and A. F. Laktionov (eds.) Annals of the International Geophysical Year, Oceanography Pergamon Press, New York: 94-112.

Gosselin, M., M. Levasseur, P. A. H. Wheeler and B. C. Bоoth, 1997: New measurements of phytoplankton and ice algal production in the Arctic Ocean. - Deep-Sea Res. Part II 44(8): 1623-1644.

GRAHL, C., 1996: Mikrobielle Aktivität und Biomasse in den Sedimenten der Laptewsee (Arktis). - In: Diplomarbeit, Universität Oldenburg: $57 \mathrm{pp}$.

GREBMEIER, J. M. and J. P. BARRY, 1991: The Influence of oceanographic processes on pelagic-benthic coupling in polar regions: A benthic perspective. - Journal of Marine Systems 2: 495-518.

Grossmann, S. and W. ReIChHARDT, 1991: Impact of Arenicola marina on bacteria in intertidal sediments. - Mar. Ecol. Prog. Ser. 77: 85-93.

Hunkins, K. L., 1961: Seismic Studies of the Arctic Ocean Floor. - Geology of the Arctic 1: 645-665.

Jensen, P., 1984: Measuring carbon contents in nematodes. - Helgoländer Meeresuntersuchungen 38: $83-86$.

KÖRNER, R. M., 1973: The mass balance of the sea ice in the Arctic Ocean. - Journal of Glaciology 12 (63): $173-185$.

MeYeR-ReIL, L.-A., 1983: Benthic response to sedimentation events during autum to spring at a shallow water station in western Kiel Bight. - Mar. Biol. 77: 247-256.

MeYer-ReIL, L.-A. and M. KösTeR, 1991: Fine scale distribution of hydrolytic activity associated with foraminifers and bacteria in deep-sea sediments of the Norwegian-Greenland Sea. - Kieler Meeresf. 8: $121-126$.

MeYeR-ReIL, L.-A. and M. Köster, 1992: Microbial life in pelagic sediments: the impact of environmental parameters on enzymatic degradation of organic material. - Mar. Ecol. Prog. Ser. 81: 65-72.

Nürnserg, D., I. Wollensburg, D. DethlefF, H. Eicken, H. Kassens, T. Letzig, E. Reimnitz and J. THIEDE, 1994: Sediments in the Arctic sea ice: Implications for entrainment transport and release. - Marine Geology 119: 185-214.

PfannKuche, O., 1992: Organic carbon flux through the benthic community in the temperate abyssal northeast Atlantic. - In: Deep Sea Food Chains and the Global Carbon Cycle. Edited by G. T. RowE and V. PARIENTE, Dordrecht Kluwer Acad. Publishers: 183-198. 
Pfannkuche, O., A. Boetius, K. Lochte, U. Lundgreen and H. Thiel, 1999: Responses of deep-sea benthos to sedimentation patterns in the North-East Atlantic in 1992. - Deep-Sea Res. I 46(4): $573-596$.

Pfannkuche, O. and T. Soltwedel, 1998: Small benthic size classes along the N.W. European Continental Margin: spatial and temporal variability in activity and biomass. - Progress in oceanography 42: 189-207.

Pfannkuche, O. and H. ThIEL, 1987: Meiobenthic stocks and benthic activity on the NE-Svalbard Shelf and in the Nansen Basin. - Polar Biology 7: 253-266.

Pivovarov, S., in prep.: A hydrological front over the Alpha Ridge in the Arctic Ocean in july 1998.

PorembA, K. and H. G. HopPe, 1995: Spatial variation of benthic microbial production and hydrolytic enzymatic activity down the continental slope of the Celtic Sea. - Mar. Ecol. Prog. Ser. 118(1-3): $237-245$.

Rajendran, N., O. Matsuda and Y. Urushigawa, 1992: Distribution of polarlipid fatty acid biomarkers for bacteria in sediments of a polluted bay. - Microbios 72(291): 143-152.

Rice, A. L., D. S. M. Billet, J. Fry, A. W. G. John, R. S. Lampit, R. F. C. Mantoura, and R. J. MorRIS, 1986: Seasonal deposition of phytodetritus to the deep-sea floor. - Proc. Roy. Soc. Edinburgh. Section B, Biology 88: 265-279.

SCHEIBE, S., 1990: Untersuchungen zur Verteilung der Meiofauna und sedimentchemischer Parameter im Nordost-Atlantik. Diploma-thesis. University of Hamburg: $126 \mathrm{pp}$.

Schewe, I. and T. Soltwedel, 1999: Deep-Sea meiobenthos of the central Arctic Ocean: Distribution patterns and size-structure under extreme oligotrophic conditions. - Vie et milieu 49(2/3): 79-92.

Shirayama, Y., 1983: Size structure of deep-sea meio-and macrobenthos in the western Pacific. - Internat. Rev. ges. Hydrobiol. 68(6): 799-810.

Soltwedel, T., 2000: Metazoan meiobenthos along continental margins: a review. - Progress in oceanography 46(1): 59-84.

Soltwedel, T., V. Mokievsky, and I. Schewe, 2000: Benthic activity and biomass on the Yermak Plateau and in adjacent deep-sea regions northwest of Svalbard. - Deep-Sea Res. I 47 (9): 1716-1785.

Soltwedel, T. and I. Schewe, 1998: Activity and biomass of the small benthic biota under permanent ice-coverage in the central Arctic Ocean. - Polar Biology 19 (1): 52-62.

StEIN, R., 1996: Organic-carbon and carbonate distribution in surface sediments from the eastern central Arctic Ocean and the Eurasian Continental Margin: Sources and pathways. - Berichte zur Polarforschung 212: 243-267.

Swift, J. H., E. P. Jones, K. Aagandd, E. C. Carmack, M. Hingston, R. W. MacDonald, F. A. McLaughlin and R. G. Perkin, 1997: Waters of the Makarov and Canada basins. - Deep-Sea Res. Part II 44(8): 1503-1529.

THIEL, H., 1983: Meibenthos and nanobenthos of the deep sea. - In: The Sea. Edited by G. T. RowE, J. Wiley \& Sons, New York, Vol. 8, Deep Sea Biology: 167-230.

Thiel, H., O. Pfannkuche, G. Schriever, K. Lochte, A. J. Gooday, C. Hemleben, R. F. C. Mantoura, C. M. Turley, J. W. Patching and F. Riemann, 1989: Phytodetritus on the deep-sea floor in a central oceanic region of the Northeast Atlantic. - Biological Oceanography 6(2): 203-239.

VENRICK, E. L., 1971: The Statistics of Subsampling. - Limnol. Oceanogr. 16 (5): 811-818.

Wassmann, P., R. Peinert and V. SmetaceK, 1991: Patterns of production and sedimentation in the boreal and polar Norteast Atlantic. - Polar Research 10: 209-228.

Wefer, G., 1989: Particle flux in the ocean: Effects of episodic production. - In: Productivity of the Ocean: Present and Past. Edited by W. H. Berger, V. S. SmetaceK, and G. Wefer, John Wiley \& Sons, New York: 139-154.

Wheeler, P. A., M. Gosselin, E. Sherr, D. Thibault, D. L. Kirchmans, R. Benner and T. E. WhitLEDGE, 1996: Active cycling of organic carbon in the Central Arctic Ocean. - Nature 380: 697-699.

Manuscipt received May 16th, 2000; revised October 4th, 2000; accepted October 16th, 2000 
